УДК 336.764.1:005.52:005.93

DOI: $10.15673 /$ fie.v10i4.1131

\author{
Купріна Н.M. \\ кандидат економічних наук, доцент \\ кафедра обліку та аудиту \\ E-mail: k.natali@ukr.net \\ Тофаніло О.А \\ магістрант \\ кафредра обліку та аудиту \\ E-mail: tofa12345@mail.ru
}

\author{
Котобан I.O. \\ магістрант \\ кафедра обліку та аудиту \\ E-mail: ira.kotoban@gmail.com \\ Скіпор P.Є. \\ магістрант \\ кафедра обліку та аудиту \\ Одеська національна академія харчових технологій \\ вул. Канатна, 112, м. Одеса, Україна, 65039 \\ E-mail: shkiperdrop@gmai.com
}

\title{
ОСОБЛИВОСТІ АНАЛІЗУ ОБОРОТНИХ АКТИВІВ ПІДПРИЄМСТВА В СУЧАСНИХ УМОВАХ
}

Досліджено понятійно-категоріальний апарат сутності категорій «оборотні активи» підприємства та їх важливих елементів - «запасів», «дебіторської заборгованості», «грошових коштів» в публікаціях вчених та П(С)БО, обґрунтовано взаємозв'язок між ними. Показано підхід до аналізу оборотних активів підприємства та їх елементів: аналіз складу, структури та динаміки як оборотних активів, так й окремих їх елементів; аналіз розміщення оборотного капіталу, який вкладено в оборотні активи підприємства; аналіз оборотності оборотних активів та їх елементів. Обґрунтована необхідність застосування аналізу впливу оборотності оборотного капіталу підприємства на ліквідність оборотних активів та його окремих елементів.

Ключові слова: оборотні активи, елементи оборотних активів, запаси, дебіторська заборгованість, грошові кошти, оборотний капітал, аналіз.

This work is licensed under a Creative Commons Attribution 4.0 International License http://creativecommons.org/licenses/by/4.0/

Постановка проблеми та їі зв'язок з важливими науковими та практичними завданнями. Ефективність функціонування будь-якого промислового підприємства не можлива без раціонального вкладення оборотного капіталу та наявності власних оборотних активів, а також без ефективного його розміщення в окремих елементах оборотних активів, структура яких суттєво впливає на фінансовий стан підприємства і платоспроможність та на ліквідність його активів. Сучасний стан підприємств промисловості характеризується нестійкої фінансової ситуаці$€ ю$, невідповідності показників ліквідності балансу нормативним значенням и, відповідно, неліквідному балансу та проблемам з можливістю термінового погашення найбільш строкових зобов'язань. Ще одною проблемою сучасного функціонування підприємства $\epsilon$ відсутність або невелика сума власного оборотного капіталу, який вкладено в його оборотні активи, що не дає можливості нормального фінансування запасів та потребує пошуку додаткових джерел їх фінансування. Тому механізм ефективного управління оборотними активами підприємства не можливий без попереднього та детального аналізу стану, динаміки, структури, ефективності використання як окремих елементів оборотних активів, так й їх в цілому, а також оцінки впливу їх оборотності на ліквідність поточних активів що підтверджує актуальність даного дослідження, основні його напрями та значення.
Аналіз останніх публікацій по проблемі. Попереднє дослідження показало [1], що аналізу теоретичних та практичних аспектів управління оборотними активами та оборотним капіталом, їх окремими елементами були присвячені публікації багатьох іноземних та вітчизняних вчених. Вагомий внесок в дослідження даної наукової проблеми внесли: І. Балабанов, С. Барнгольц, У. Баумоль, Л. Бетхіна, М. Білик, А. Бірман, І. Бланк, Ю. Брігхейм, І. Бубняк, Б. Буркинський, М. Володькіна, Ю. Воробйов, В. Гриньова, Т. Демченко, А. Золотарьов, Ф. Кене, В. Ковальов, М. Коробов, В. Коюда, Е. Локшина, Д. Мартін, А. Маршал, М. Міллер, Н. Невмержицька, О. Непочатенко, П. Осіпов, Д. Оpp, О. Павловська, А. Поддєрьогін, Н. Притуляк, Р. Радіонов, Л. Ротштейн, Н. Русак, Р. Славюк, А. Сміт, Л. Соляник, Р. Сорока, С. Стоянова, О. Терещенко, Д. Томкінс, О. Філімоненков, А. Шило, Й. Шумпетер та ін., але не втрачають своєї актуальності в теперішній час та потребують додаткових досліджень. Так, ефективне управління оборотними активами та їх окремими елементами не можливе без даних, які характеризують об'єкт дослідження в попередніх періодах (його динаміку, структуру, ефективність використання тощо) тому необхідно вибрати саме такій методичний підхід до проведення економічного аналізу і послідовність дослідження, що дозволить управлінському 
персоналу підприємства розробити ефективні напрямі управління ними і обгрунтувати вибір тих елементів оборотних активів, які є важливими. Тому об' єктом дослідження в даної статті є оборотні активи та їх елементи, а предметом - економічний аналіз оборотних активів промислового підприємства.

Формування цілей дослідження. Основною метою дослідження $є$ визначення сутності важливих елементів оборотних активів, таких як запаси, дебіторська заборгованість, грошові кошти, управління якими мають важливе значення в сучасних умовах функціонування підприємств та формування підходу для проведення аналізу оборотних активів підприємства та їх окремих елементів на прикладі даних фінансової звітності підприємства харчової промисловості Одеської області з метою підвищення ефективності їх використання.

Виклад основних результатів та їх обгрунтування. Попереднє дослідження сутності категорій «оборотні активи» та «оборотний капітал підприємства показало, що оборотні активи є лише частиною поточних активів (оборотних коштів) та частиною оборотного капіталу та вони будуть дорівнювати поточним активам (оборотним коштам) підприємства у разі відсутності у підприємства необоротних активів, утримуваних для продажу, та груп вибуття. Таким чином, поточні активи підприємства - оборотні кошти підприємства, в який вкладено його оборотний капітал [1].

Відповідно до Національного положення (стандарту) бухгалтерського обліку 1 «Загальні вимоги до фінансової звітності», затвердженого наказом Міністерства фінансів України від 07.02.2013 №73 (НП(С)БО 1) [2], оборотні активи підприємства - це «гроші та їх еквіваленти, що не обмежені у використанні, а також інші активи, призначені для реалізації чи споживання протягом операційного циклу чи протягом дванадцяти місяців 3 дати балансу, а важливими елементами, які впливають на ліквідність балансу $\epsilon$ дебіторська заборгованість, запаси та, особливо, грошові кошти підприємства». Відповідно до НП(С)БО 1 [2], грошові кошти (гроші) - «готівка, кошти на рахунках у банках та депозити до запитання». Грошові кошти підприємства, як найліквідніші активи, включають готівку в касі, кошти на рахунках в банках, електронні гроші, які емітуються у відкрито циркулюючій системі, депозити до запитання та кошти в дорозі. Як правило, для підприємств промисловості, даний елемент оборотних активів $є$ найменш вагомим в їх структурі, що відображає сучасний фінансовий стан багатьох підприємств.

Як показало попереднє дослідження [3], дебіторська заборгованість складає біле половини величини всіх оборотних активів та на деяких підприємствах досягає 80-90\% й формується, в основному, 3 дебіторської заборгованості покупців (замовників) за поставку товарів, надання послуг або виконанні роботи, тому управління саме дебіторською заборгованістю підприємства пов'язано з оптимізацією іiі розміру та забезпеченням інкасації заборгованості покупців (замовників) за розрахунками за реалізовану продукцію або надані послуги чи виконані роботи.

Відповідно до П(С)БО 10 [4], Дебіторська заборгованість - «сума заборгованості дебіторів підприємству на певну дату», яка поділяється на довгострокову (сума дебіторської заборгованості, яка не виникає в ході нормального операційного циклу та буде погашена після дванадцяти місяців 3 дати балансу) та поточну дебіторську заборгованість (сума дебіторської заборгованості, яка виникає в ході нормального операційного циклу або буде погашена протягом дванадцяти місяців з дати балансу).

Сучасний стан промислових підприємств та їх функціонування призвели до виникненню деяких категорій, пов'язаних с дебіторською заборгованістю та негативно характеризують управління нею, а саме: сумнівний борг - «поточна дебіторська заборгованість, щодо якої існує невпевненість іiі погашення боржником», що потребує визначення у Формі №1 «Баланс (Звіт про фінансовий стан)» визначення додаткової статті (показника) та чиста реалізаційна вартість

дебіторської заборгованості - це сума поточної дебіторської заборгованості за вирахуванням резерву сумнівних боргів [4].

Запаси, як третій вагомий елемент оборотних активів підприємства, відповідно до П(С)БО 9 [5] - це «активи, які:

- утримуються для подальшого продажу (розподілу, передачі) за умов звичайної господарської діяльності;

- перебувають у процесі виробництва з метою подальшого продажу продукту виробництва;

- утримуються для споживання під час виробництва продукції, виконання робіт та надання послуг, а також управління підприємством/установою».

Важливість управління даним елементом оборотних активів є в тому, що нераціональна закупівля запасів веде до значного відволікання грошових коштів 3 обороту підприємства, виникнення псування запасів та додаткових витрат на їх утримання та обслуговування.

Дослідження показало, що не існує єдиного підходу до визначення сутності категорій «запаси», «дебіторська заборгованість», «грошові кошти» підприємства відповідно до задач і напрямів дослідження та методів управління.

Так, запаси - це:

- «все те, на що є попит, але що в даний момент виключено з виробничого або особистого споживання, це всі матеріальні, фінансові, трудові та інші ресурси, які в даний момент не використовуються» $[6$, с.8];

- «матеріальні цінності, оборотні кошти у вигляді сировини, матеріалів, палива, напівфабрикатів, готової продукції, які не використовуються в даний момент у виробництві, що зберігаються на складах або в інших місцях і призначені для наступного використання» [7, с.113];

- «будь-який ресурс, який використовується для того, щоб задовольнити поточну або майбутню 
потребу (заготовки та вихідні матеріали, напівфабрикати, що перебувають у виробничому процесі і готові вироби» [8, с. 95];

- активи, які використовуються для подальшого продажу, використання під час виробництва продукції, виконання робіт і надання послуг, а також управління підприємством [9, с. 313] тощо.

Дебіторська заборгованість - це:

- «сума заборгованості підприємству, якщо існує ймовірність отримання майбутніх економічних вигід та може бути достовірно визначена іiі сума» [10, с. 198];

- «сума боргів, належних організації, які виникли в процесі господарських взаємовідносин 3 юридичними або фізичними особами» [11, с. 48];

- «різновид боргових зобов'язань і визначається наявністю тимчасового розриву між продажем товару та / або наданням послуги та її оплатою, виділяються дві підстави: перше пов'язане 3 наданням покупцям відстрочки (розстрочки) платежу за відвантажену продукцію, а друге - 3 здійсненням авансових платежів самою організацією» [12, с. 48];

- «досить динамічний елемент оборотних коштів, який суттєво залежить від прийнятої в компанії політики щодо покупців продукції» [13] .
Грошові кошти визначаються, як:

- «гроші - одне з найдавніших явищ у житті суспільства - відіграють важливу роль у його економічному і соціальному розвитку» [14];

- «гроші - це сукупність активів, які люди регулярно використовують для придбання товарів i послуг у інших індивідів» [15];

- «гроші стають абсолютним товаром, який протистоїть на ринку всім іншим товарам, стає мірилом вартості останніх і безпосереднім втіленням багатства взагалі» [16].

Таким чином, все вище наведене підтверджує необхідність ефективного управління як оборотними активами, тай й важливими їх елементами, а першим етапом такого управління $\epsilon$ проведення їх якісного економічного аналізу, а саме аналіз складу, структури та динаміки як оборотних активів, так й окремих їх елементів; аналіз розміщення оборотного капіталу, який вкладено в оборотні активи підприємства; аналіз оборотності оборотних активів та їх елементів (табл. 1-4) за даними фінансової звітності підприємства харчової промисловості Одеської області, а саме 3 виробництва какао, шоколаду та цукрових кондитерських виробів.

Таблиця 1

Аналіз складу, структури та динаміки оборотних активів*

\begin{tabular}{|c|c|c|c|c|c|c|c|c|c|}
\hline \multirow[b]{2}{*}{ Показники } & \multirow[b]{2}{*}{ Код рядка } & \multicolumn{2}{|c|}{$\begin{array}{c}\text { Абсолютна } \\
\text { величина }\end{array}$} & \multicolumn{2}{|c|}{ Питома вага, \% } & \multicolumn{4}{|c|}{ Відхилення } \\
\hline & & 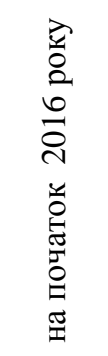 & 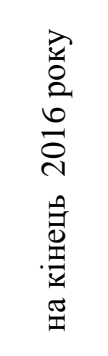 & 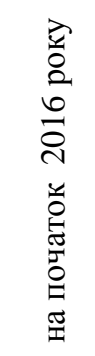 & 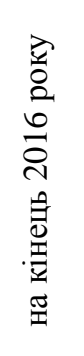 & 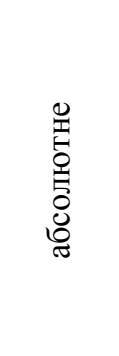 & 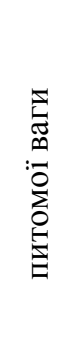 & 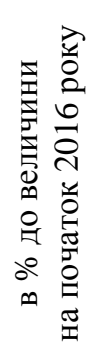 & 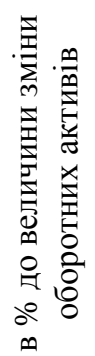 \\
\hline $\begin{array}{l}\text { Оборотні активи } \\
\text { всього, тис. грн., } \\
\text { в тому числі: } \\
\end{array}$ & 1195 & 40141 & 28670 & 100 & 100 & -11471 & $\mathrm{x}$ & $-28,6$ & 100 \\
\hline - запаси & 1100 & 18678 & 14188 & 46,5 & 49,5 & -4490 & 3 & -24 & 39,1 \\
\hline $\begin{array}{l}\text { - дебіторська } \\
\text { заборгованість }\end{array}$ & $\begin{array}{c}1120 \div \\
1155\end{array}$ & 21223 & 14290 & 52,9 & 49,8 & -6933 & -3 & $-32,7$ & 60,4 \\
\hline $\begin{array}{l}\text { - грошові кошти та } \\
\text { поточні фінансові } \\
\text { інвестиції }\end{array}$ & $\begin{array}{l}1160 \\
1165\end{array}$ & 96 & 192 & 0,2 & 0,7 & 96 & 0,4 & 100 & $-0,8$ \\
\hline $\begin{array}{l}\text { - інші оборотні ак- } \\
\text { тиви }\end{array}$ & $\begin{array}{l}1170 \\
1190\end{array}$ & 144 & - & 0,40 & - & -144 & $-0,4$ & -100 & 1,3 \\
\hline
\end{tabular}

* складено та розраховано авторами на підставі фінансової звітності підприємства

Дослідження показників в табл. 1 свідчать, що у звітному 2016 році спостерігались наступні зміни:

- оборотні активи на кінець 2016 року,в порівнянні з початком 2016 року, зменшились на 11471 тис. грн., або на 28,6\%. Це відбулося за рахунок зменшення запасів на 4490 тис. грн., або на $24 \%$ та дебіторської заборгованості на 6933 тис. грн., або на $32,7 \%$, а також збільшення грошових коштів на 96 тис. грн., або на 100\%;

- в структурі оборотних активів на початок звітного року: найбільшу питому вагу займала дебіторська заборгованість - 52,9\%, питома вага запасів склала $-46,5 \%$, грошових коштів - 0,2\%. Структура оборотних активів на кінець звітного року значно не змінилась. 
Аналіз структури розміщення оборотного капіталу (оборотних коштів) підприємства за сферами розміщення його окремих елементів здійснюється за на підставі даних форм №1 «Баланс (Звіт про фінансовий стан)» та №5 «Примітки до річної фінансової звітності» за допомогою табл. 2.

Таблиця 2

Аналіз структури розміщення оборотного капіталу підприсмства*

\begin{tabular}{|c|c|c|c|c|c|c|c|}
\hline \multirow{3}{*}{ Показники } & \multirow{2}{*}{\multicolumn{2}{|c|}{2015 рік }} & \multirow{2}{*}{\multicolumn{2}{|c|}{2016 рік }} & \multicolumn{3}{|c|}{ Відхилення } \\
\hline & & & & & \multirow{2}{*}{ абс. } & \multirow{2}{*}{$\%$} & \multirow{2}{*}{$\begin{array}{c}\text { за струк- } \\
\text { турою }\end{array}$} \\
\hline & тис. грн.. & $\%$ & тис. грн. & $\%$ & & & \\
\hline $\begin{array}{l}\text { 1. Сфера виробництва } \\
\text { в тому числі: }\end{array}$ & 15500 & 38,6 & 13099 & 45,7 & -2401 & $-15,5$ & 7,1 \\
\hline - виробничі запаси & 13310 & 33,2 & 11584 & 40,4 & -1726 & -13 & 7,2 \\
\hline - незавершене виробництво & 2188 & 5,5 & 1515 & 5,30 & -673 & $-30,8$ & $-0,2$ \\
\hline $\begin{array}{l}\text { - витрати майбутніх періо- } \\
\text { дів }\end{array}$ & 2 & 0,0 & - & - & -2 & $-100,0$ & $-0,0$ \\
\hline $\begin{array}{l}\text { 2. Сфера обігу? } \\
\text { в тому числі: }\end{array}$ & 24641 & 61,4 & 15571 & 54,3 & -9070 & $-36,8$ & $-7,1$ \\
\hline - готова продукція & 3180 & 7,9 & 1089 & 3,8 & -2091 & $-65,8$ & $-4,1$ \\
\hline - грошові кошти & 96 & 0,2 & 192 & 0,7 & 96 & 100,0 & 0,4 \\
\hline - дебіторська заборгованість & 21233 & 52,9 & 14290 & 49,8 & -6933 & $-32,7$ & $-3,0$ \\
\hline - товари & - & - & - & - & - & - & - \\
\hline - інші & 142 & 0,4 & - & - & -142 & $-100,0$ & $-0,4$ \\
\hline Всього оборотний капітал & 40141 & 100 & 28670 & 100 & -11471 & $-28,6$ & - \\
\hline
\end{tabular}

* складено та розраховано авторами на підставі фінансової звітності підприємства

Дослідження показників в табл. 2. свідчать, що у 2016 році в порівнянні з 2015 роком спостерігались наступні зміни:

- загальна величина оборотного капіталу зменшилась на 11471 тис. грн., або на 28,6\%. Цьому сприяло: зменшення капіталу у сфері виробництва на 2401 тис. грн., або на 15,5\%, зменшення в сфері обігу на 9070 тис. грн., або на 36,8 \%.

в структурі оборотного капіталу 2015 року, найбільша питома вага капіталу сфери обігу $61,4 \%$, а питома вага в сфері виробництва $-38,6 \%$. В
2016 році в порівнянні з 2015 роком, відбулися зміни в структурі оборотного капіталу: зменшилась питома вага капіталу на $7,1 \%$ пункти, розміщеного в сфері обігу, та збільшилась питома вага в сфері виробництва - на 7,1\% пункти.

Аналіз складу, структури та динаміки дебіторської заборгованості підприємства, як й других елементів оборотних активів - запасів та грошових коштів, здійснюється підставі даних форми №1 «Баланс (Звіт про фінансовий стан)» за допомогою табл. 3.

Таблиця 3

Аналіз складу, структури та динаміки дебіторської заборгованості*

\begin{tabular}{|c|c|c|c|c|c|c|c|c|c|}
\hline \multirow[b]{2}{*}{ Показники } & \multirow[b]{2}{*}{$\begin{array}{c}\text { Код } \\
\text { рядка }\end{array}$} & \multicolumn{2}{|c|}{$\begin{array}{c}\text { Абсолютна } \\
\text { величина }\end{array}$} & \multicolumn{2}{|c|}{ Питома вага, \% } & \multicolumn{4}{|c|}{ Відхилення } \\
\hline & & 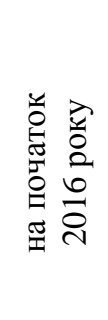 & 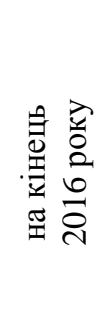 & 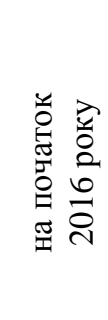 & 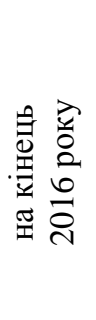 & 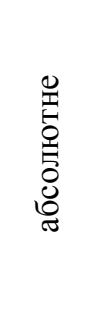 & 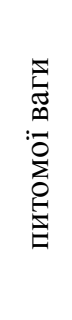 & 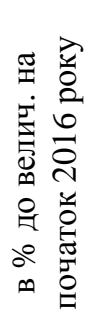 & 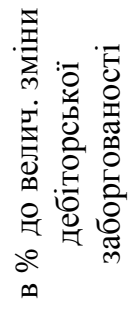 \\
\hline $\begin{array}{l}\text { Дебіторська заборгова- } \\
\text { ність всього, } \\
\text { в тому числі: }\end{array}$ & $1125 \div 1155$ & 21223 & 14290 & 100 & 100 & -6933 & $\mathrm{x}$ & $-32,7$ & 100 \\
\hline $\begin{array}{l}\text { 1.1.Дебіторська забор- } \\
\text { гованість за товари, } \\
\text { роботи, послуги* }\end{array}$ & $\begin{array}{l}1120 \\
1125\end{array}$ & 15298 & 10022 & 75,1 & 70,1 & -5906 & $-4,9$ & $-37,1$ & 85,2 \\
\hline
\end{tabular}


Продовження табл.3

\begin{tabular}{|c|c|c|c|c|c|c|c|c|c|}
\hline \multirow[b]{2}{*}{ Показники } & \multirow[b]{2}{*}{$\begin{array}{c}\text { Код } \\
\text { рядка }\end{array}$} & \multicolumn{2}{|c|}{$\begin{array}{c}\text { Абсолютна } \\
\text { величина }\end{array}$} & \multicolumn{2}{|c|}{ Питома вага, \% } & \multicolumn{4}{|c|}{ Відхилення } \\
\hline & & 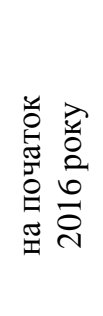 & 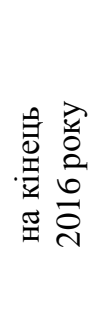 & 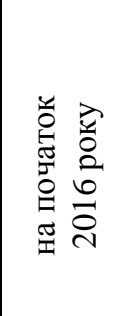 & 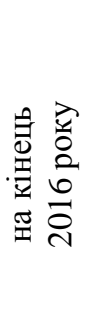 & 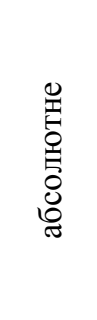 & 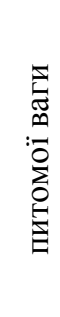 & 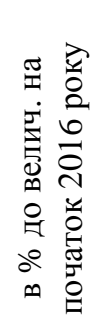 & 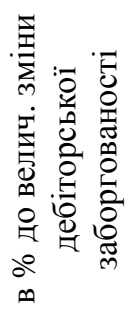 \\
\hline $\begin{array}{l}\text { 1.2.Дебіторська забор- } \\
\text { гованість за розрахун- } \\
\text { ками: }\end{array}$ & $\begin{array}{c}1130 \div \\
1145\end{array}$ & 5295 & 4268 & 24,9 & 29,9 & -1027 & 4,9 & $-19,0$ & 14,8 \\
\hline - за виданими авансами & 1130 & 5295 & 4268 & 24,9 & 29,9 & -1027 & 4,9 & $-19,4$ & 14,8 \\
\hline - 3 бюджетом & 1135 & - & - & - & - & - & - & - & - \\
\hline $\begin{array}{l}\text { - в тому числі з подат- } \\
\text { ку на прибуток }\end{array}$ & 1136 & - & - & - & - & - & - & - & - \\
\hline $\begin{array}{l}\text { - } 3 \text { нарахованих дохо- } \\
\text { дів }\end{array}$ & 1140 & - & - & - & - & - & - & - & - \\
\hline $\begin{array}{l}\text { - із внутрішніх розра- } \\
\text { хунків }\end{array}$ & 1145 & - & - & - & - & - & - & - & - \\
\hline $\begin{array}{l}\text { 1.3.Інша поточна дебі- } \\
\text { торська заборгованість }\end{array}$ & 1155 & - & - & - & - & - & & - & - \\
\hline
\end{tabular}

* складено та розраховано авторами на підставі фінансової звітності підприємства

Дослідження показників в табл. 3 свідчать, що у 2016 році в порівнянні з 2015 роком дебіторська заборгованість на кінець 2016 року зменшилась на 6933 тис. грн., або на 32,7\%. Це відбулося за рахунок зменшення: дебіторської заборгованості за товари, роботи, послуги на 5906 тис. грн., або на 37,1\%.; заборгованості за розрахунками на 1027 тис. грн. або на
19\%. Таке зменшення дебіторської заборгованості позитивно впливає на фінансовий стан підприємства.

Аналіз використання оборотного капіталу (оборотних коштів) підприємства та його окремих елементів здійснюється на підставі даних форм №1 «Баланс (Звіт про фінансовий стан)» та №2 «Звіт про фінансові результати (Звіт про сукупний дохід)» за допомогою табл. 4.

Таблиця 4

Аналіз використання оборотних коштів*

\begin{tabular}{|c|c|c|c|c|c|}
\hline \multirow{2}{*}{ Показники } & \multirow{2}{*}{$\begin{array}{c}\text { Код рядка } \\
\text { (алгоритм } \\
\text { розрахунку) }\end{array}$} & \multirow{2}{*}{$\begin{array}{c}2015 \\
\text { рік }\end{array}$} & \multirow{2}{*}{$\begin{array}{c}2016 \\
\text { рік }\end{array}$} & \multicolumn{2}{|c|}{ Відхилення } \\
\hline & & & & абс. & $\%$ \\
\hline $\begin{array}{l}\text { 1. Чистий дохід від реалізації продук- } \\
\text { ції (товарів, робіт, послуг), тис. грн. }\end{array}$ & $\begin{array}{l}\text { Ф № } 2 \\
\text { p. } 2000\end{array}$ & 95549 & 48156 & -47393 & $-49,6$ \\
\hline $\begin{array}{l}\text { 2. Середньорічні залишки оборотних } \\
\text { коштів, тис. грн., в т.ч. }\end{array}$ & $\begin{array}{l}\text { Ф № } 1 \\
\text { p. } 1195\end{array}$ & 48569,5 & 34405,5 & -14164 & $-29,2$ \\
\hline 2.1. Запаси & $\Phi$ № 1 p.1100 & 22333 & 16433 & -5900 & $-26,4$ \\
\hline 2.2. Кошти в розрахунках & $\begin{array}{c}\Phi \text { № } 1 \\
\text { p. } 1125 \div 1155\end{array}$ & 25532,5 & 17756,5 & -7776 & $-30,5$ \\
\hline $\begin{array}{l}\text { 2.3. Грошові кошти та поточні фінан- } \\
\text { сові інвестиції }\end{array}$ & $\begin{array}{c}\Phi \text { № } 1 \\
\text { p.1160, } 1165\end{array}$ & 619 & 144 & -475 & $-76,7$ \\
\hline 2.4. Інші оборотні активи & $\begin{array}{c}\text { Ф № } 1 \\
\text { p.1170, } 1190\end{array}$ & 85 & 72 & -13 & $-15,3$ \\
\hline 3. Кількість днів в періоді & $\mathrm{x}$ & 360 & 360 & $\mathrm{X}$ & $\mathrm{x}$ \\
\hline 4. Одноденна виручка, тис. грн.. & p. $1:$ p. 3 & 265,41 & 133,77 & $-131,65$ & $-49,6$ \\
\hline $\begin{array}{l}\text { 5. Потреба в оборотних коштів одного } \\
\text { дня, тис. грн. }\end{array}$ & p. $2:$ p. 3 & 134,92 & 95,57 & $-39,34$ & $-29,2$ \\
\hline $\begin{array}{l}\text { 6. Кредиторська заборгованість, } \\
\text { тис.грн. }\end{array}$ & Ф № 1 p.1615 & 19248 & 15645 & -3603 & $-0,2$ \\
\hline 7. Коефіцієнт оборотності & p.1:p.2 & 1,97 & 1,4 & $-0,57$ & $-28,9$ \\
\hline
\end{tabular}




\begin{tabular}{|c|c|c|c|c|c|}
\hline \multicolumn{6}{|c|}{ Продовження табл. } \\
\hline \multirow{2}{*}{ Показники } & \multirow{2}{*}{$\begin{array}{c}\text { Код рядка } \\
\text { (алгоритм } \\
\text { розрахунку) }\end{array}$} & \multirow{2}{*}{$\begin{array}{l}2015 \\
\text { рік }\end{array}$} & \multirow{2}{*}{$\begin{array}{c}2016 \\
\text { рік }\end{array}$} & \multicolumn{2}{|c|}{ Відхилення } \\
\hline & & & & абс. & $\%$ \\
\hline 8. Коефіцієнт завантаженості & p. $2:$ p. 1 & 0,51 & 0,71 & 0,21 & 40,6 \\
\hline 9. Тривалість 1 обороту, днів, в т.ч. & $\begin{array}{l}\text { p. } 3: \text { p. } 7 \text { або } \\
\text { p. } 2: \text { p. } 4\end{array}$ & 183 & 257,2 & 74,2 & 40,6 \\
\hline 9.1. В запасах & p.2.1:p.4 & 84,1 & 122,8 & 38,7 & 46 \\
\hline 9.2. В коштах в розрахунках & p.2.2:p.4 & 96,2 & 132,7 & 36,5 & 38 \\
\hline 9.3. В грошових коштах & p.2.3:p.4 & 2,3 & 1,1 & $-1,3$ & $-53,8$ \\
\hline 9.4. В інших оборотних коштах & p. $2.4:$ p.4 & 0,3 & 0,5 & 0,2 & 68,1 \\
\hline $\begin{array}{l}\text { 10. Надлишок (економія) } \\
\text { оборотних коштів, тис. грн. }\end{array}$ & $\begin{array}{l}\text { абс. відхи- } \\
\text { лення по } \\
\text { p.9- р.5 за зві- } \\
\text { тний рік } \\
\end{array}$ & $\mathrm{x}$ & 7092,31 & $\mathrm{x}$ & $\mathrm{x}$ \\
\hline $\begin{array}{l}\text { 11.Кредиторська заборгованість, вра- } \\
\text { ховуючи економію (надлишок) оборо- } \\
\text { тних коштів при умові роботи заводу } \\
\text { на рівні попереднього року, тис. грн. }\end{array}$ & $\begin{array}{l}\text { p.10 } 10 \text { p. } 6 \text { за } \\
\text { звітний рік }\end{array}$ & $\mathrm{x}$ & 8552,69 & $\mathrm{x}$ & $\mathrm{x}$ \\
\hline
\end{tabular}

* складено та розраховано авторами на підставі фінансової звітності підприємства

Дослідження показників в табл. 4 свідчать, що у 2016 році в порівнянні з 2015 роком спостерігались наступні зміни: ефективність використання оборотних коштів підприємства погіршилась, це свідчить про збільшення коефіцієнту завантаженості на 0,21 , та зменшення коефіцієнту оборотності на 0,57 або 28,9\%; тривалість одного обороту збільшилась на 24,7 днів (за рахунок збільшення часу перебування коштів у запасах - на 38,7 днів, в коштах в розрахунках - на 36,5 днів, в інших оборотних коштах - на 0,2 дні). Це призвело до залучення додаткової суми оборотних коштів у розмірі 7092,31 тис. грн. Якщо оборотні кошти використовувались би на рівні 2015 року, то кредиторська заборгованість склала 8552,69 тис. грн., що значно менше їі поточної величини.

В умовах ринкової економіки, ліквідність активів підприємства $є$ важливим показником його функціонування та можливості залучення додаткових інвестицій, формуючим взаємовідносини 3 фінансовими установами та кредиторами, тому важливим етапом аналізу оборотних активів та їх елементів $\epsilon$ оцінка впливу оборотності на ліквідність активів підприємства, яку необхідно проводити за розробленою методикою [17, с. 59-66]

Висновки та перспективи подальших досліджень. В результаті даного наукового дослідження можна зробити наступні висновки:
1. Аналіз праць вчених та Положень (стандартів) бухгалтерського обліку щодо визначення сутності понятійно-категоріального апарату категорій «оборотні активи», «запаси», «дебіторська заборгованість», «грошові кошти», як важливих елементів оборотних активів показав, що існує безліч підходів, але вони залежать від поставлених задач, напрямів і методів дослідження.

2. Для ефективного функціонування підприємства необхідно ефективне управління як оборотними активами, так й важливими їх елементами - дебіторською заборгованістю і запасами для запобігання відволікання грошових коштів з обороту підприємства, а також грошовими коштами 3 метою збільшення їх величини, ліквідності активів балансу, ефективного розміщення вільного залишку грошових коштів, що не можливо без проведення їх детального економічного аналізу.

3. Показано підхід до аналізу оборотних активів підприємства та їх елементів, який охоплює: аналіз складу, структури та динаміки як оборотних активів, так й окремих їх елементів; аналіз розміщення оборотного капіталу, який вкладено в оборотні активи підприємства; аналіз оборотності оборотних активів та їх елементів та обгрунтована необхідність застосування аналізу впливу оборотності оборотного капіталу підприємства на ліквідність оборотних активів та його окремих елементів.

\section{Література}

1. Купріна Н.М., Черненко I.О. Оборотні активи підприємства: теоретичний та практичний аспект [Електронний ресурс]. Режим доступу: : https://journals.onaft.edu.ua/index.php/fie/article/view/863 (дата звернення 15.10.2018).

2. Загальні вимоги до фінансової звітності: Національне положення (стандарт) бухгалтерського обліку 1: затв. наказом Мінфіну від 07.02.2013 №73 за станом на 03.08.2018 p. URL: http://zakon.rada.gov.ua/laws/show/z0336-13 (дата звернення: 15.10.2018)

3. Купріна Н.М., Рудюк І. Аналіз підходів до сутності та класифікації дебіторської заборгованості підприємства // Економіка харчової промисловості. 2017. Вип. 2. Т.9. С.24-32. 
4. Дебіторська заборгованість: Положення (стандарт) бухгалтерського обліку 10: затв. наказом Мінфіну від 08.10.1999 №237 за станом на 27.06.2013 p. URL:https://buhgalter911.com/normativnaya-baza/instr-planrah/standart-buhgalterskogo/pologhennya-standart-buhgaltersykogo-1021475.html (дата звернення: 10.10.2018)

5. Запаси: Положення (стандарт) бухгалтерського обліку 9: затв. наказом Мінфіну від 20.10.1999 №246 за станом на 17.12.2012p. URL: https://buhgalter911.com/normativnaya-baza/instr-plan-rah/standartbuhgalterskogo/pologhennya-standart-buhgaltersykogo-1021474.html (дата звернення: 10.10.2018).

6. Савкович В.А. Модели управления запасами / под ред. М.И. Балашевича. Мн. : Наука и техника, 1986. $319 \mathrm{c}$.

7. Райзберг Б.А. Лозовский Л.Ш., Стародубцева Е.Б. Современный экономический словарь / Райзберг Б.А. 2-е изд. исправ. М.: Инфра, 1998. 479 с.

8. Козловский В.А., Козловская Э.А., Савруков Н.Т. Логистический менеджмент. СПб.: Политехника 1999. -275 c.

9. Бутинець Ф. Ф. Бухгалтерський фінансовий облік: підручник для студентів спеціальності «Облік і аудит» вищих навчальних закладів / Ф.Ф. Бутинець. Житомир: ПП «Рута», 2009. 912 с.

10. Цал-Цалко Ю.С. Фінансовий аналіз: підручник. Київ: ЦУЛ, 2008. 566 с.

11. Купріянова Л.М., Болдирєв О.М. Оцінка ефективності управління дебіторською заборгованістю // Світ нової економіки. 2015. №2 [Електронний ресурс]. URL: http://cyberleninka.ru/article/n/otsenkaeffektivnosti-upravleniya-debitorskoy-zadolzhennostyu. (дата звернення: 1.10.2018).

12. Єрофєєва В.А., Смолякова В.А. Системний підхід до управління дебіторською заборгованістю // Тһе Management accounting Journal. 2011. №2 [Електронний pecypc]. URL: http://www.upruchet.ru/articles/2011/2/5517.html. (дата звернення: 1.10.2018).

13. Шутько Г.М.,Рахімова Р.P. Управління дебіторською заборгованістю підприємства // SCI-ARTICLE. 2016. №1 [Електронний pecypc]. URL: http://sci-article.ru/stat.php?i=1451314370. (дата звернення: 1.10.2018).

14. Бутинець Ф.Ф. Теорія бухгалтерського обліку: підручник для студентів вузів спеціальності 7.050106 “Облік і аудит”. - Житомир: ЖІТІ, 2000. - 640с.

15. Голов С.Ф., Костюченко В.М. Бухгалтерський облік за міжнародними стандартами: приклади та коментарі: практичний посібник. К: Лібра, 2013. 55с.

16. Ковалев В.В.Финансовый анализ: методы и процедуры. М: Финансы и статистика, 2001. 560 с.

17. Купріна Н.М. Аналіз ліквідності активів в організаційно-економічному механізмі оптимального управління оборотним капіталом підприємств харчової промисловості // Управління фінансово-економічною безпекою підприємств харчової промисловості України: аналіз та синтез методів: монографія / Немченко В.В. та ін. за заг. ред. д.е.н., проф. В.В. Немченко. Одеська, національна, академія харчових технологій. Одеса: Фенікс, 2013. С. 59-66.

Стаття надійшла 20.10.2018

Стаття прийнята до друку 4.11.2018 Доступно в мережі Internet 29.12.2018

Куприна Н.M.

кандидат экономических наук, доцент кафедра учета и аудита E-mail: k.natali@ukr.net

Тофанило А.A. кафредра учета и аудита E-mail: tofa12345@mail.ru

\author{
Котобан И.О. \\ магистрант \\ кафедра учета и аудита \\ E-mail: ira.kotoban@gmail.com
}

Скипор P.E.

магистрант

кафедра учета и аудита

Одесская национальная академия пищевых технологий ул. Канатная, 112, г. Одесса, Украина, 65039

E-mail: shkiperdrop@gmai.com

\section{ОСОБЕННОСТИ АНАЛИЗА ОБОРОТНЫХ АКТИВОВ ПРЕДПРИЯТИЯ В СОВРЕМЕННЫХ УСЛОВИЯХ}

Основной целью исследования является понятийно-категориальный аппарат сущности категорий «оборотные активы» предприятия и их важных элементов - «запасов», «дебиторской задолженности», «денежных средств» в публикациях ученых и П(С)БУ, обоснована взаимосвязь между ними, и формирование подхода к проведению анализа оборотных активов предприятия и их важных элементов.

В процессе исследования использовались методы: теоретического обобщения (для исследования и выделения понятийного аппарата категорий); сравнительного анализа (для определения сущности категорий на основании анализа подходов ученых в научных публикациях и П(С)БУ); ме- 
тод абсолютных и относительных величин (для анализа оборотных активов и их элементов для эффективного управления ими) системного анализа и синтеза (для анализа эффективности их использования).

Исследование показало, что оборотные активы предприятия - это деньги и их эквиваленты, не ограниченные в использовании, а также другие активы, предназначенные для реализации или потребления в течение операционного цикла или в течение двенадцати месяцев с даты баланса, а важными элементами, которые влияют на ликвидность баланса, является дебиторская задолженность, запасы и, особенно, денежные средства предприятия. Анализ работ ученых и Положений (стандартов) бухгалтерского учета по определению сущности понятийно-категориального аппарата категорий «оборотные активы», «запасы», «дебиторская задолженность», «денежные средства», как важных элементов оборотных активов показал, что существует множество, подходов которые зависят от поставленных задач, направлений и методов исследования. Для эффективного фрункционирования предприятиям необходимо эффективное управление как оборотными активами, так и важными их элементами - дебиторской задолженностью и запасами для предотвращения отвлечения денежных средств из оборота предприятия, а также денежными средствами с целью увеличения их величины, ликвидности активов баланса, эффективного размещение свободного остатка денежных средств, что невозможно без проведения детального экономического их анализа. Показано подход к анализу оборотных активов предприятия и их элементов, который охватывает анализ состава, структуры и динамики как оборотных активов, так и отдельных их элементов; анализ размещения оборотного капитала, вложенного в оборотные активы предприятия; анализ оборачиваемости оборотных активов и их элементов и обоснована необходимость применения анализа влияния оборачиваемости оборотного капитала предприятия на ликвидность оборотных активов и их отдельных элементов.

Ключевые слова: оборотные активы, элементы оборотных активов, запасы, дебиторская задолженность, денежные средства, оборотный капитал, анализ.

\author{
Kuprina N. \\ Ph.D., Associate Professor \\ Department of Accounting and Auditing \\ E-mail:k.natali@ukr.net \\ Tofanilo 0. \\ Undergraduate \\ Department of Accounting and Auditing \\ E-mail: tofa12345@mail.ru
}

\author{
Kotoban I. \\ Department of Accounting and Auditing \\ E-mail: ira.kotoban@gmail.com
}

\author{
Skipor R. \\ Undergraduate \\ Department of Accounting and Auditing \\ Odessa National Academy of Food Technologies \\ Kanatna str., 112, Odesa, Ukraine, 65039 \\ E-mail: shkiperdrop@gmai.com
}

\section{FEATURES OF THE ANALYSIS OF REVERSIBLE ASSETS OF THE ENTERPRISE IN MODERN CONDITIONS}

The main purpose of the study is the conceptual and categorical apparatus of the essence of the "current assets" categories of an enterprise and their important elements - "stocks", "receivables", "cash", a reasonable relationship was substantiated between them and discussed in scientific publications and $P(C)$ $\mathrm{BU}$ and the formation of the approach of the analysis of current assets of the enterprise and their important elements was explained.

In the process of the research, the following methods were used: theoretical generalization (for research and identification of the conceptual apparatus of categories); comparative analysis (to determine the nature of categories based on the analysis of the approaches of scientists in scientific publications and $P(C)$ $\mathrm{BU}$ ); the method of absolute and relative values (for analyzing current assets and their elements for their effective management) system analysis and synthesis (for analyzing the effectiveness of their use).

The study showed that current assets of an enterprise are "money and cash equivalents not restricted in use, as well as the other assets intended for sale or consumption during the operating cycle or within twelve months from the balance sheet date, but the important elements that affect balance sheet liquidity is accounts receivable, stocks and, especially, funds of the enterprise. The analysis of the work of scientists and Regulations (standards) of accounting to determine the essence of the conceptual and categorical apparatus of the categories "current assets", "stocks", "receivables", "cash" as important elements of current assets showed that there are many approaches that depend on the tasks, directions and methods of the research. For effective functioning, enterprises need effective management of both current assets and their important elements - receivables and inventories to prevent the diversion of funds from the company's 
turnover, as well as cash in order to increase their value, balance sheet assets liquidity, effective allocation of free cash balance that is impossible without their detailed economic analysis. The approach to the analysis of current assets of the enterprise and their elements, which covers the analysis of the composition, structure and dynamics of both current assets and their individual elements, has been shown; the analysis of the placement of working capital invested in the current assets of the company; the analysis of the turnover of current assets and their elements and the need to analyze the impact of the turnover of the company's working capital on the liquidity of current assets and their individual elements has been substantiated.

Keywords: current assets, elements of current assets, stocks, accounts receivable, cash, working capital, analysis.

\section{References}

1. Kuprina, N. M., \& Chernenko, I. O. (2018). Oborotnì aktivi pìdpriêmstva: Teoretičnij ta praktičnij aspekt. Retrieved October 15, 2018, from https://journals.onaft.edu.ua/index.php/fie/article/view/863

2. Zagal'nì vimogi do fìnansovoï zvìtnostì: Nacìonal'ne položennâ (standart) buhgalters'kogo oblìku 1: Zatv. nakazom Mìnfìnu vìd 07.02.2013 №73 za stanom na 03.08.2018 r. (2018). Retrieved October 15, 2018, from http://zakon.rada.gov.ua/laws/show/z0336-13

3. Kuprina, N. M., \& Rudiuk, I. (2017). Analìz pìdhodìv do sutnostì ta klasifìkaciï debìtors'koï zaborgovanostì pìdpriêmstva. Ekonomika Harčovoï Promislovostì, 9(2), 24-32.

4. Debìtors'ka zaborgovanìst': Položennâ (standart) buhgalters'kogo oblikku 10: Zatv. nakazom Mìnfìnu vìd 08.10.1999 №237 za stanom na 27.06.2013 r. (2013). Retrieved October 10, 2018, from https://buhgalter911.com/normativnaya-baza/instr-plan-rah/standart-buhgalterskogo/pologhennya-standartbuhgaltersykogo-1021475.html

5. Zapasi: Položennâ (standart) buhgalters'kogo oblìku 9: Zatv. nakazom Mìnfìnu vìd 20.10.1999 №246 za stanom na 17.12.2012r. (2012). Retrieved October 10, 2018, from https://buhgalter911.com/normativnaya-baza/instrplan-rah/standart-buhgalterskogo/pologhennya-standart-buhgaltersykogo-1021474.html

6. Savkovich, V. A. (1986). Modeli upravleniâ zapasami (M. I. Balashevich, Ed.). Mn.: Nauka i tehnika.

7. Rayzberg, B. A., Lozovskiy, L. Sh., \& Starodubtseva, E. B. (1998). Sovremennyj èkonomičeskij slovar' (2nd ed.). Moskva: Infra.

8. Kozlovskiy, V. A., Kozlovskaya, E. A., \& Savrukov, N. T. (1999). Logističeskij menedžment. SPb.: Politehnika.

9. Butynets, F. F. (2009). Buhgalters'kij finansovij oblik: Pidručnik dlâ studentìv special'nostì «Oblik ì audit» visih navčal'nih zakladiv. Zhytomyr: $\mathrm{PP}$ «Ruta».

10. Tsal-Tsalko, Yu. S. (2008). Finansovij analiz. Kyiv: CUL.

11. Kupriianova, L. M., \& Boldyriev, O. M. (2015). Ocìnka efektivnostì upravlìnnâ debìtors'koû zaborgovanìstû. Svit Novoï Ekonomiki, (2). Retrieved October 01, 2018, from http://cyberleninka.ru/article/n/otsenkaeffektivnosti-upravleniya-debitorskoy-zadolzhennostyu

12. Yerofieieva, V. A., \& Smoliakova, V. A. (2011). Sistemnij pìdhìd do upravlìnnâ debìtors'koû zaborgovanìstû. The Management Accounting Journal, (2). Retrieved October 01, 2018, from http://www.upruchet.ru/articles/2011/2/5517.html

13. Shutko, H. M., \& Rakhimova, R. R. (2016). Upravlìnnâ debìtors'koû zaborgovanìstû pìdpriêmstva. SCIARTICLE, (1). Retrieved October 01, 2018, from http://sci-article.ru/stat.php?i=1451314370

14. Butynets, F. F. (2000). Teoriâ buhgalters'kogo obliku. Zhytomyr: ŽÌTÌ.

15. Holov, S. F., \& Kostiuchenko, V. M. (2013). Buhgalters'kij oblik za mižnarodnimi standartami: Prikladi ta komentari. Kyiv: Libra.

16. Kovalev, V. V. (2001). Finansovyj analiz: Metody i procedury. Moskva: Finansy i statistika.

17. Kuprina, N. M. (2013). Analìz lìkvìdnostì aktivìv v organìzacìjno-ekonomìcnomu mehanìzmì optimal'nogo upravlìnnâ oborotnim kapìtalom pìdpriêmstv harčovoï promislovostì. In V. V. Nemchenko (Ed.), Upravlinnâ finansovoekonomičnoû bezpekoû pidpriêmstv harčovoï promislovostì Ukraïni: Analiz ta sintez metodìv (pp. 59-66). Odesa: Feniks.

Received 20 October 2018 Approved 4 November 2018 Available in Internet 29.12.2018

Цитування згідно ДСТУ 8302:2015

Купріна Н.М., Котобан I.О., Тофаніло О.А., Скіпор Р.С. Особливості аналізу оборотних активів підприємства в сучасних умовах // Економіка харчової промисловості. 2018. Т. 10, Вип. 4. С39-47. doi: 10.15673/fie.v10i4.1131

Cite as APA style citation

Kuprina N., Kotoban I., Tofanilo O., \& Skipor R. (2018). Features of the analysis of reversible assets of the enterprise in modern conditions. Food Industry Economics, 10(4), 39-47;doi: 10.15673/fie.v10i4.1131 